\title{
MISCFLLANEA GEOGRAPHICA
}

WARSZAWA 1990

\section{Maria Stopa-Boryczka}

\section{THE CLIMATE OF POLAND AGAINST A BACKGROUND OF CLIMATES OF THE NORTHERN HEMISPHERE}

The main features of Poland's climate resulting from its geographical position in moderate latitudes of central Europe have been presented in this paper.

This required the distinguishing of climate variability features, i.e. longitudinal (zonal), determined by the geographical latitude; latitudinal, caused by polar and continental air masses circulation; and hypsometric, stemming from differences in the altitude above the sea level (StopaBoryczka, Boryczka 1974, 1976, 1989).

The chief empirical models simulating spatial variability of climatic elements in Poland are the equations of regression hyperplanes in relation to geographical coordinates $\varphi, \lambda$ and the altitude above sea level (Table 1).

Table 1

Annual changeability rate of mean state of atmosphere in Poland

\begin{tabular}{|l|l|r|r|r|r|}
\hline $\begin{array}{l}\text { Sym- } \\
\text { bols }\end{array}$ & \multicolumn{1}{|c|}{ Neteorological variables } & Min & Max & $\bar{y}$ & Units \\
\hline \multirow{T}{*}{} & Air temperature & -3.4 & 17.3 & 7.2 & ${ }^{\circ} \mathrm{C}$ \\
$T_{\max }$ & Maximum temperature & 0.1 & 22.8 & 11.2 & ${ }^{\circ} \mathrm{C}$ \\
$T_{\min }$ & Minimum temperature & -8.5 & 12.3 & 2.9 & ${ }^{\circ} \mathrm{C}$ \\
$A$ & Diurnal range & 6.9 & 11.7 & 8.5 & ${ }^{\circ} \mathrm{C}$ \\
$e$ & Water vapour pressure & 4.5 & 15.6 & 9.1 & $\mathrm{hPa}$ \\
$\varphi^{\prime}$ & Absolute humidity & 3.6 & 11.6 & 7.0 & $\mathrm{~g} / \mathrm{m}^{3}$ \\
$q$ & Specific humidity & 2.8 & 9.8 & 5.7 & $\mathrm{~g} / \mathrm{kg}$ \\
$f$ & Relative humidity & 72.0 & 88.0 & 80.0 & $0 / 0$ \\
$\Delta$ & Humidity deficit & 0.8 & 5.7 & 3.0 & $\mathrm{hPa}$ \\
$N$ & Cloudiness & 5.7 & 7.9 & 6.6 & $1 / 10$ \\
$O$ & Atmospheric precipitation & 32.4 & 103.9 & 52.8 & $\mathrm{~mm}$ \\
$p$ & Atmospheric pressure & 989.1 & 994.1 & 991.0 & $\mathrm{hPa}$ \\
$v$ & Wind velocity & 2.7 & 4.1 & 3.3 & $\mathrm{~m} / \mathrm{s}$ \\
& & & & & \\
\hline
\end{tabular}




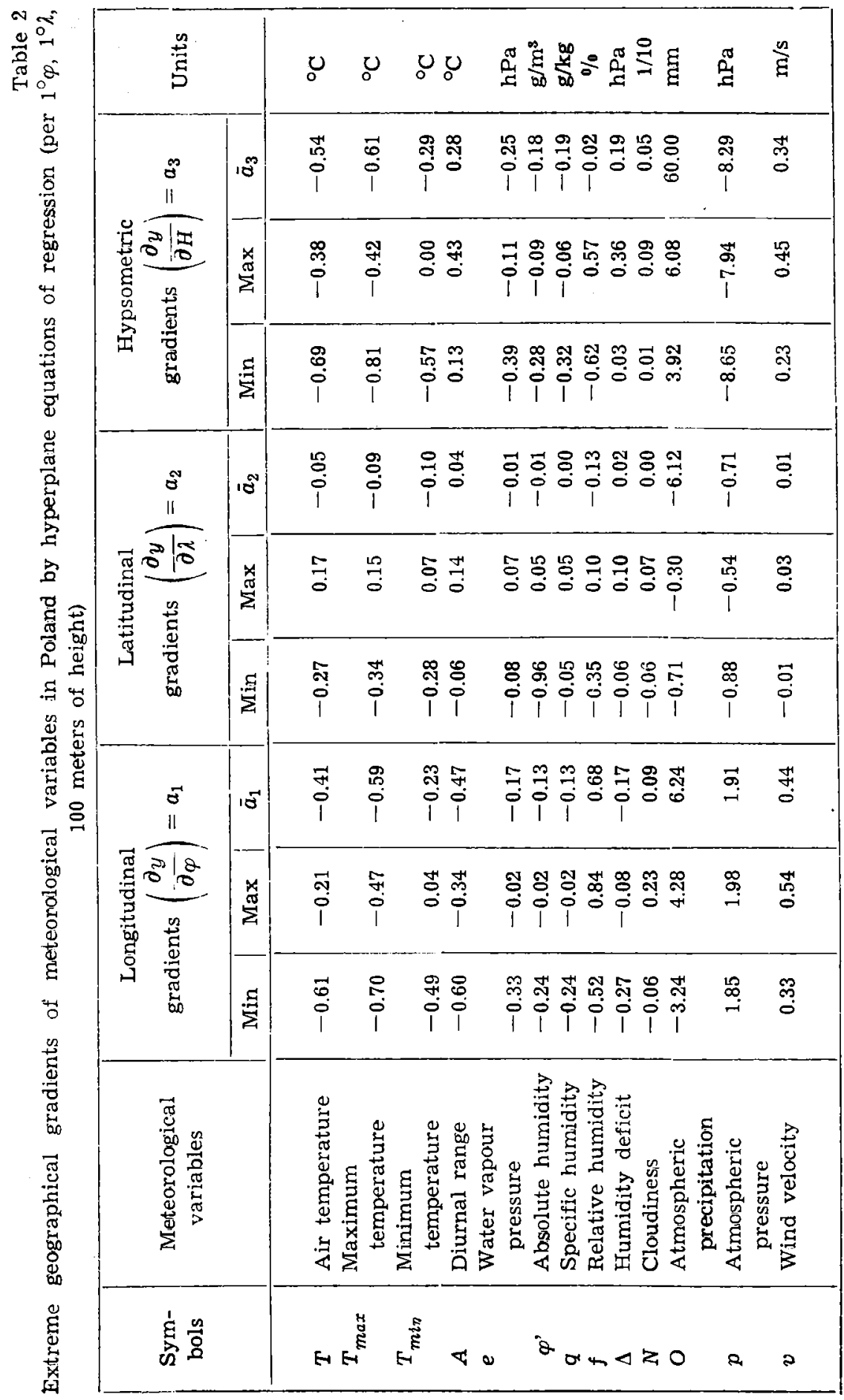


Deformation of meteorological variables field by the Earth's relief is of important cognitive value. Precise maritime and continental climate features in Poland have been found through eliminating the effect of the altitude above sea level on the meteorological variables field.

Latitudinal meteorological variables gradients determined by the hyperplane regression equations are measures of the oceanism (continentalism). The main feature of these gradients in Poland is the change of the sign value during the year: from positive in summer to negative in winter. This evidences the transitory nature of Poland's climate, that is the prevalence of oceanic features in the west and of continental features in the east of the country. Latitudinal air temperature field gradients are positive in the warm half-year and negative in the cool one. Thus, air temperature increases towards the east in summer months and decreases in winter months. Latitudinal humidity gradients follow a similar pattern. For example, absolute humidity in winter is higher in the west than in the east part of the country.

The basic pattern of investigation of climatic zones in Poland consists of the mean and average longitudinal gradients in moderate and other latitudes of the Northern Hemisphere (Table 1, 2; Figs. 1-4).

First, the comparison has been made of the mean atmospheric values $(y)$ of the principal variables: total sunshine, air temperature and humidity, cloudiness, precipitation, atmospheric pressure from the whole territory of Poland (of an average latiture $\bar{\varphi}=51.8$ ) with an average state of atmosphere at this latitude $(\bar{Y})$. Dependence of some chosen variables on the geographical latitude in Northern Hemisphere is shown by curves $\bar{Y}(\bar{\varphi})$ in Figs. 1-2 (after Khromow, 1969 and Witwicki, 1980). The difference $\Delta y=y-\bar{Y}$, where $\bar{Y}$ is the average corresponding to Poland's latitude, obtained by crossectioning curve $Y(\varphi)$ with line $\varphi=51.8$, is a measure of climate peculiarity in Poland.

As in moderate latitudes meteorological variables, especially air temperature and absolute humidity, range fairly large amplitudes, extreme months were distinguished: January, which represents winter, and July, characteristic of the summer, and the year.

Against a background of its geographical position, Poland is characterized in winter by higher values of

- air temperature

- water vapour pressure

- absolute humidity

- relative humidity

- cloudiness by $4.7 \mathrm{C}$,

by $1.8 \mathrm{hPa}$,

by $1.8 \mathrm{~g} / \mathrm{m}^{3}$,

by $3 \%$,

by $2.8(.9)$, and lower

6 Miscellanea Geographica 

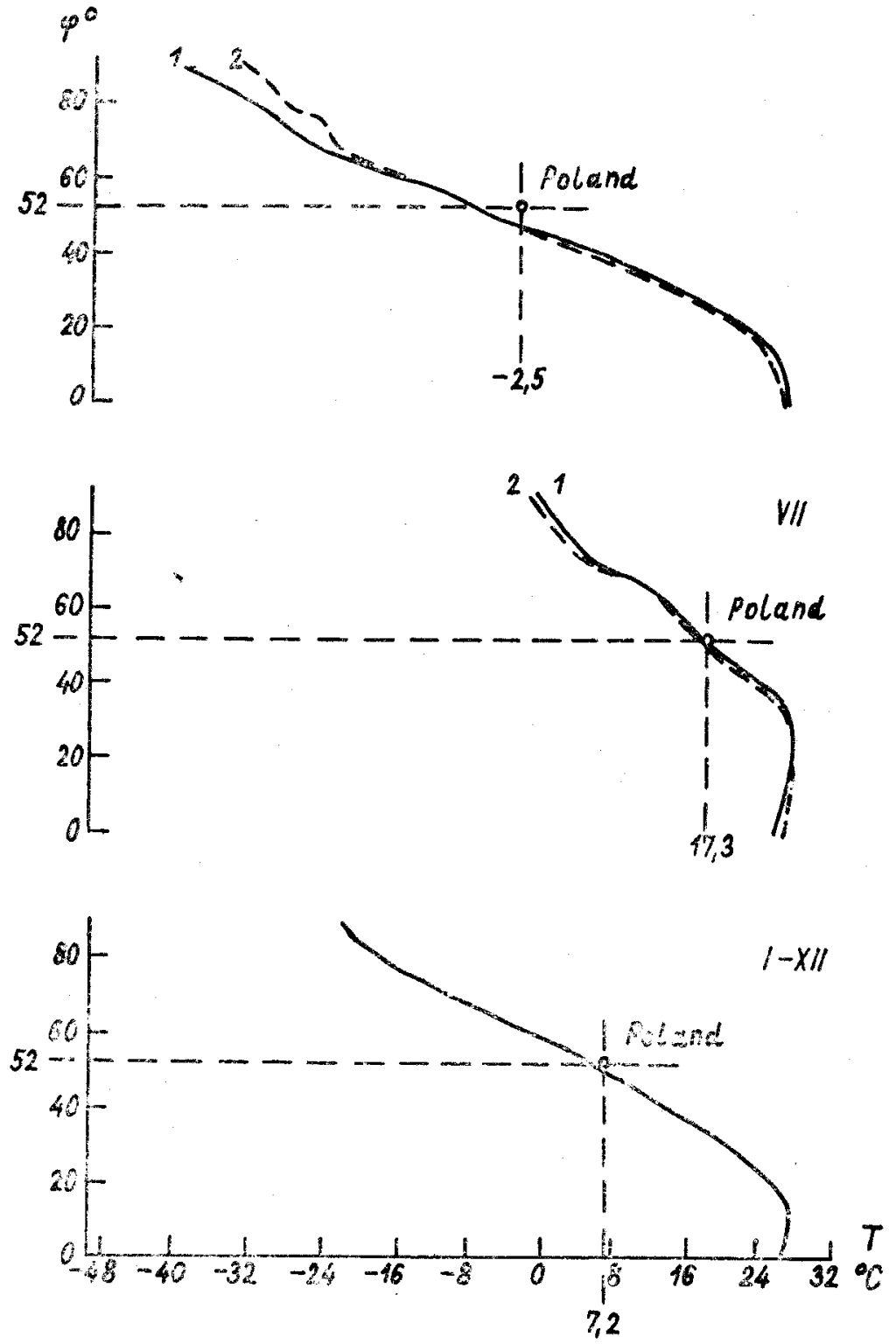

Fig. 1. Relationship of temperature $(T)$ to geographical latitude in the Northern Hemisphere: January, July, annual (afeer Khromow (1) and Witwicki (2)) 

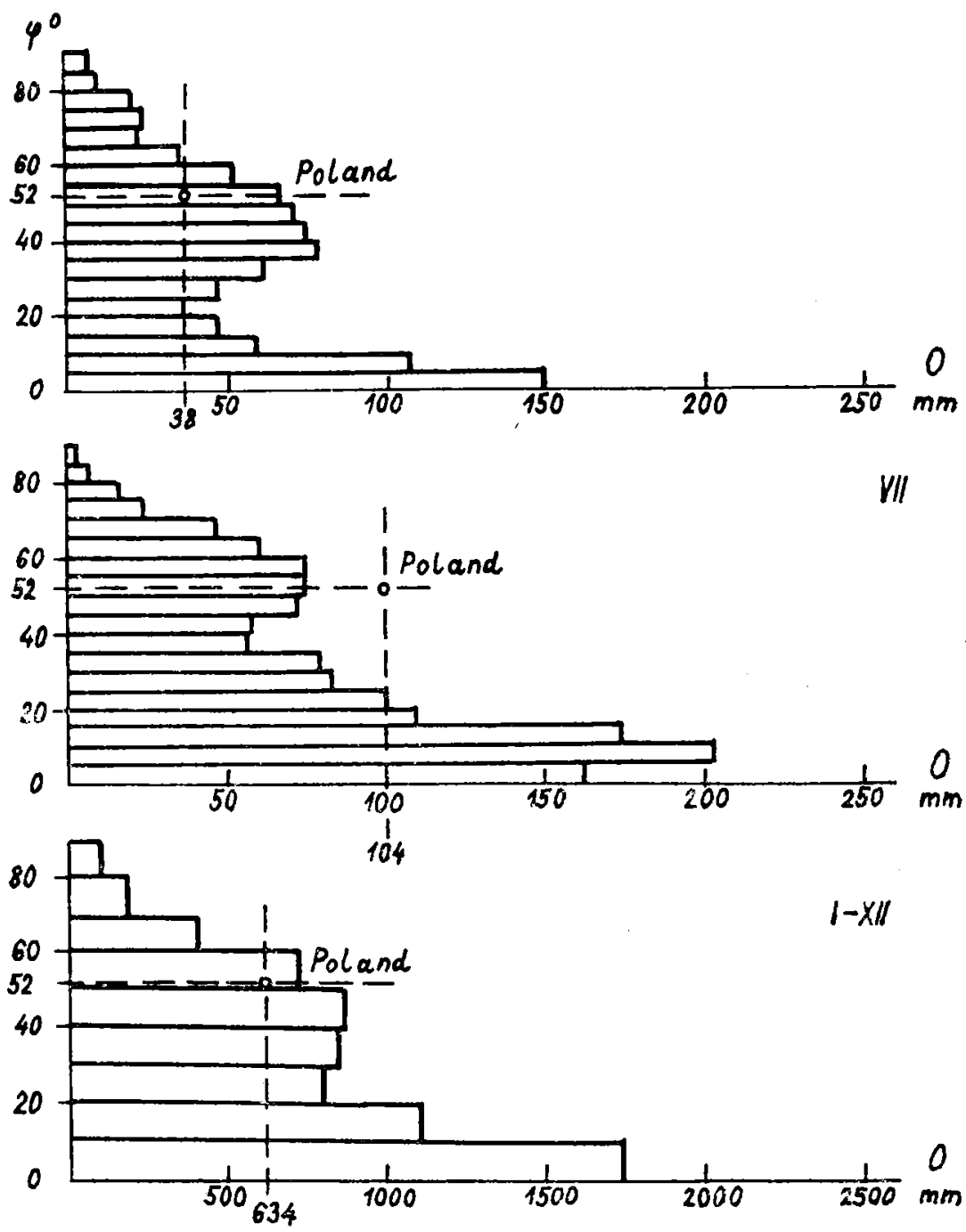

Fig. 2. Relationship of totals of precipitation $(O)$ to geographical latitude in the Northern Hemisphere: January,July, annual

values of

- total radiation sums

- atmospheric pressure

by $3.5 \mathrm{~kJ} / \mathrm{cm}$ month,

- atmospheric precipitation totals

by $4 \mathrm{hPa}$,

by $29 \mathrm{~mm}$.

On the other hand, the mean state of atmoshere in summer does not differ much from an average value of meteorological variables in the vicinity of latitude $52^{\circ}$. Extreme values of absolute sunshine (June), 
humidity and cloudiness (July) are higher on the average than mean values at latitude $52^{\circ}$. Humidity and cloudiness in Poland are, irrespective of the season, higher than it is indicated by the geographical position at moderate latitudes of central Europe. It should be noted that large winter cloudiness distinguishes Poland not only from moderate latitudes but also from the whole of the Northern Hemisphere, This also applies to the mean annual cloudiness. Annual precipitation totals are lower by $100 \mathrm{~mm}$ than the norm $(\varphi=52)$, which equals $734 \mathrm{~mm}$.

The main features of meteorological field variables were described by comparing mean gradients of air temperature and humidity, cloudiness, precipitation and atmospheric pressure from the whole territory of Poland (characterized by hyperplane regression equations), with mean gradients of moderate latitudes along the parallel of $\varphi=51.8^{\circ}$ of latitude.

The relation of longitudinal air temperature, humidity and precipitation gradients with the geographical latitude in the Northern Hemisphere is illustrated by the curves in Figs. 3 and 4 (partly based on data from Khromov (1969) and Witwicki (1980)).

Differences between gradients obtained in the territory of Poland and the whole moderate zone point out the peculiarity of Poland's climate central Europeanl.

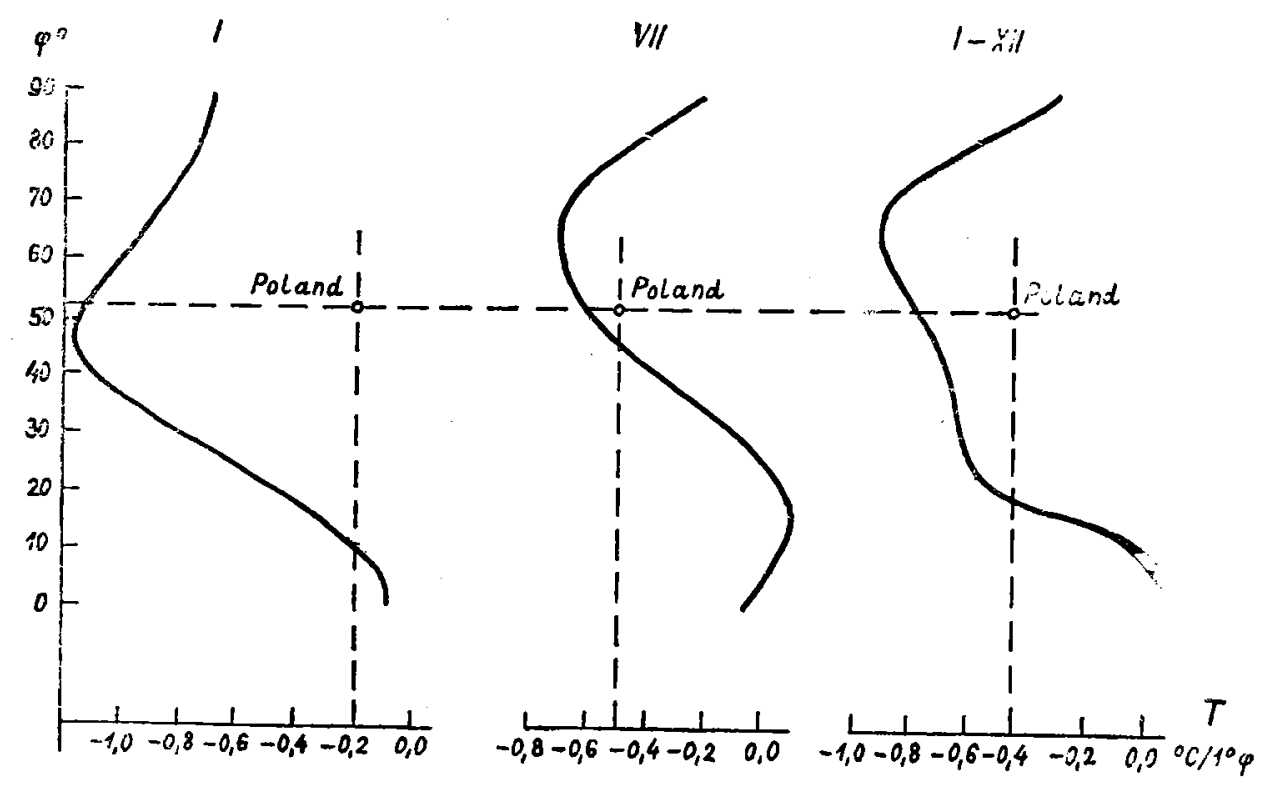

Fig. 3. Relationship of longitudinal air temperature gradients $\left(\frac{\partial O}{\partial \varphi}\right)$ to geographical latitude in the Northern Hemisphere 


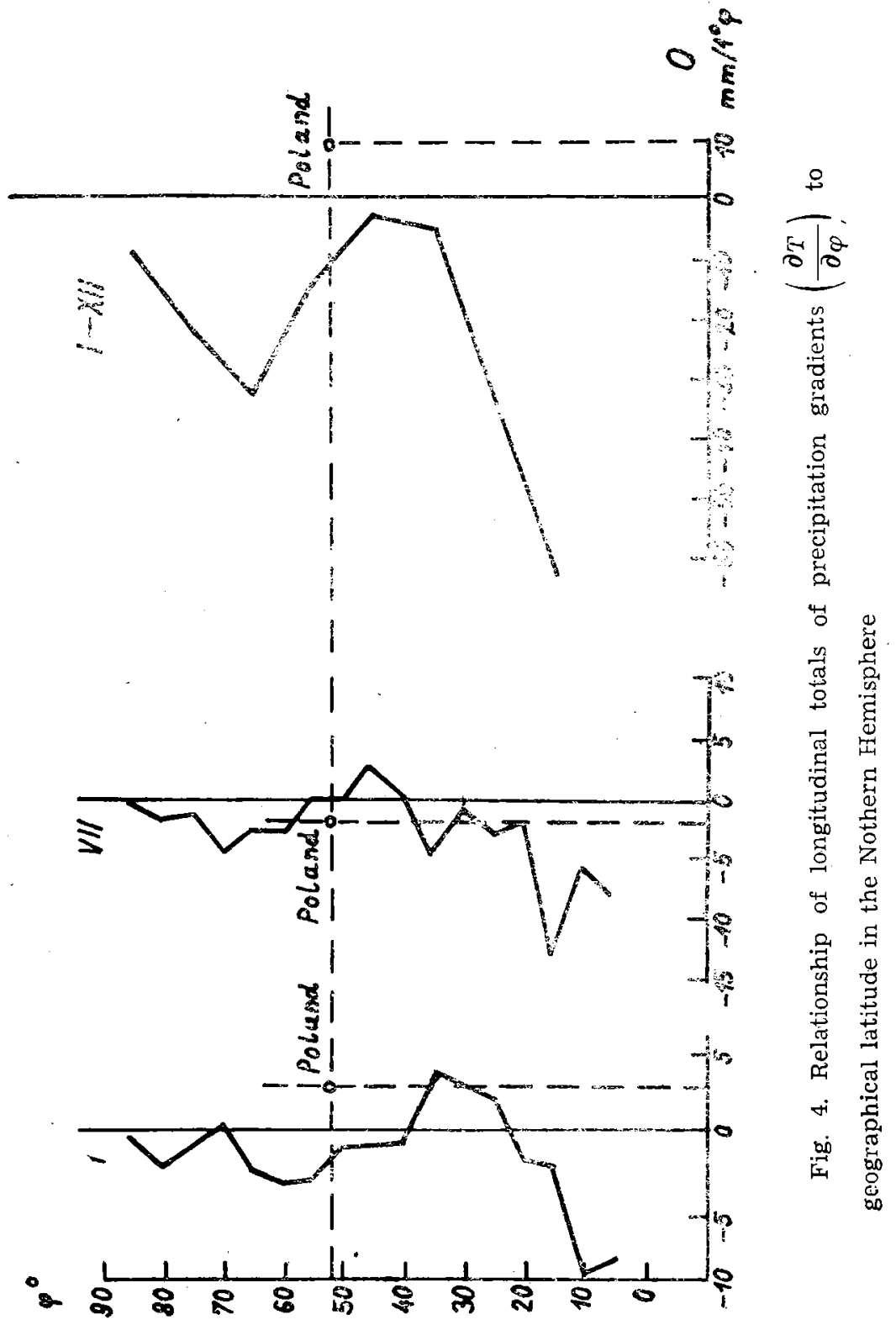


Against a background of latitude $52^{\circ}$, Poland is characterized above all in winter by smaller longitudinal gradients of:

- air temperature

- water vapour pressure

- absolute humidity by $1.0 \mathrm{C} / 1$,

by $.3 \mathrm{hPa}$,

by $.2 \mathrm{~g} / \mathrm{m}^{3}$.

Higher gradients of different sign value, in relation to latitude $52^{\circ}$, are typical, first of all, of pressure and precipitation, thus showing considerable azonalty of meteorological variables fields in the cold halfyear.

Meteorological variables fields give a better evidence of zonalty in summer months.

The mean state of atmosphere is determined above all by its geographical position, i.e. the appropriate latitudinal zone. Sun radiation depends on the latitude, its elevation and duration of daytime in the particular seasons. Sun's energy absorbed on the Earth's surface affects the intensity of physical processes occurring in the atmosphere, thus conditioning meteorological variable fields.

The distance from water reservoirs is an azonal characteristics in moderate latitudes. Central European variable field deformation (deviation from zonal standards) depends on the distance from the Atlantic Ocean and from Central Asia, where the main atmospheric activity centres are the Icelandic low pressure and the Azorian high pressure active throughout the year, as well as the Asian high pressure centre (southern Siberia) active in winter. These centres have an overwhelming effect on climate differentiation along the latitudes. Land relief in Poland - belt-like lowlands - favours oceanic air masses movement from the west to the east and that of the continental masses in the opposite direction. Such highlands as in the Masurian and Pomeranian Lake Districts, the Małopolska Highland or the Lublin Highland, are too small obstacles to the latitutinal air masses circulation. This specific position of Poland in relation to the most active low and high pressure centres in the Northern Hemisphere is the cause of great variability in pressure arrangement and the accompanying air masses. It results in considerable deformation of meteorological variables fields over Poland. Recognition of the main geographical features affecting Poland's climate and an attempt at comparing them with other latitudes are of great importance for modeling and forecasting its temporal and spatial changes.

Similar problems were considered by Ewert (1984) on the example of the north-western Poland, and earlier by Hess et al. (1968, 1979), Michna and Poczos (1972) for the case of the mountains. 


\section{REFERENCES}

Khromov, S.P., 1977, Metodologia i klimatologia (Meteorology and Climatology), Warszawa.

Ewert, A., 1984, Opady atmosferyczne na obszarze Polski w przekroju rocznym (Atmospheric Precipitation over the Area of Poland in the Annual Profile), Wydawnictwa Wyższej Szkoły Pedagogicznej w Słupsku, Słupsk.

Hess, M., 1968, "Piętra klimatyczne w Alpach Wschodnich, Karpatach Zachodnich i w Sudetach" (Climatic Floors in the East Alps, Western Carpathians and in the Sudeten Mts), Przeglad Geograficzny, Vol. XL, No. 2.

Hess, M., Niedźwiedź, T., O brębska-Starklowa B., 1979, "O zróżnicowaniu stosunków termicznych w dorzeczu górnej Wisly" (Differentiation of Thermal Relation in the Upper Vistula Basin), Folia Geographica, Series Geographica-Physica, Vol. XII.

Michna, E., Pachos, S., 1972, Zarys klimatu Bieszczadów Zachodnich (Outline of Climate of the Western Bieszczad Mts.), Wrocław-Warszawa-Krakow-Gdańsk.

S t o p a-B or y c zka, M., B or y czk a J., 1989, Atlas wspótzależności parametrów meteorologicznych $i$ geograficznych $w$ Polsce (The Atlas of Interdependence of Meteorological and Geographical Parameters in Poland), Part I, Warszawa 1974, Part II 1976, Part V.

W it w i cki, G. N., 1980, Zonalnost klimata ziemli (Zonalty of the Earth's Climate), Moskva. 
